\title{
Компьютерная визуализация русской языковой картины мира
}

\author{
П. Чжан, В. П. Захаров \\ Санкт-Петербургский государственный университет \\ zhangpl@yandex.ru, v.zakhrov@spbu.ru
}

\section{Аннотация}

В статье рассматривается визуализация русской языковой картины мира. Языковая картина мира является представлением о мире, сложившимся в обыденном сознании данного языкового коллектива. Концепт представляет собой основную единицу языковой картины мира, которая может реализоваться в слове, словосочетании, высказывании, дискурсе, тексте и т.д. Семантические поля, с помощью которых можно описывать лексическую систему языка, являются отражениями концептов. Существует много способов представления семантических полей: интеллект-карта, сервис RusVectōrēs, Облако тегов и т.д. Анализ словарных толкований слов, в которых отражается заданный концепт, является одной из основных методик представления концептов.

В статье мы анализируем русскую языковую картину мира на примере трех концептов: империя, государство, власть с помощью словарных статей слов империи, государства и власти из разных толковых словарей русского языка. В работе описываются разные способов визуализации семантических полей. Рассматриваются интеллект-карты как один из важных способов визуализации семантических полей слов, в которых отражаются концептов. Также описывается программное обеспечение для формирования интеллект-карт, в частности, MindMeister, XMind, Freemind, MindManager, и Coogle. Этот документ описывает правила оформления научных статей для публикации в трудах Всероссийской объединенной конференции «Интернет и современное общество».

Ключевые слова: языковая картина мира, концепт, визуализация знаний, интеллекткарта

Библиографическая ссылка: Чжан П., Захаров В. П. Компьютерная визуализация русской языковой картины мира // Компьютерная лингвистика и вычислительные онтологии. Выпуск 3 (Труды XXII Международной объединенной научной конференции «Интернет и современное общество», IMS-2019, Санкт-Петербург, 19 22 июня 2019 г. Сборник научных трудов). — СПб: Университет ИТМО, 2019. С. 92 -105. DOI: 10.17586/2541-9781-2019-3-92-105

\section{1. Введение. Языковая картина мира}

Один и тот же язык, один и тот же общественно-исторический опыт формирует у членов определенного общества сходные представления о мире. Картина мира лежит в основе как индивидуального, так и общественного сознания. Исторически представление о картине мира восходит к идеям немецкого лингвиста и философа В. фон Гумбольдта и опирается на идеи И. Гердера о природе и происхождении языка, о взаимосвязи языка, мышления и «духа народа», также на идеи Ф. Шлегеля о сущности нации. Тесная связь мышления и языка позволяет выделить ее особую разновидность картины мира - языковую картину мира (ЯКМ). Гумбольдт писал, что представления человека о мире зависят от того языка, 
которым он пользуется. У каждого языка есть своя внутренняя форма; языки отличаются друг от друга не только звуковыми, материальными оболочками смыслов, но и самим способом восприятия мира, что позволяет говорить о некой обобщенной национальной языковой картине мира. Задачей описания ЯКМ занимаются когнитивная лингвистика, психолингвистика, компьютерная лингвистика, каждая с использованием своих методов.

\section{2. Концепты и семантические поля}

Основной единицей языковой картины мира являются концепт. Концепт как ментальная сущность имеет национально-специфические черты, соотносимые с мировидением, культурой, обычаями, верованиями и историей народа. В концептах аккумулируется как культурный уровень каждой языковой личности, так и всех носителей языка в целом.

Концепты как основные элементы языковой картины мира, могут реализоваться в слове, словосочетании, высказывании, дискурсе, тексте и т.д. Они образуют внутреннюю основу семантических полей. «Власть», «государство» и «империя» являются важными концептами у многих народов, а в русской языковой картине мира они занимают особое место.

Семантические поля, с помощью которых можно описывать лексическую систему языка, фактически, являются «овеществленными» отражениями концептов. Впервые термин "семантическое поле" был введен Г. Ипсеном [1]. Поле обычно рассматривается как совокупность языковых единиц, объединенных каким-то общим семантическим признаком; имеющих некоторый общий компонент значения. Семантический признак, лежащий в основе семантического поля, может также рассматриваться как некоторая понятийная категория (А.В. Бондарко, Л.М. Васильев, И.М. Кобозева). В трактовке В.Г. Адмони [2] поле характеризуется наличием инвентаря элементов, связанных системными отношениями. По мнению В. Г. Адмони, в поле можно выделить центральную часть - ядро, элементы которого обладают полным набором признаков, определяющих данную группировку, и периферию, элементы которой обладают не всеми, характерными для поля признаками, но могут иметь и признаки, присущие соседним полям.

\section{3. Методы выявления семантических полей}

В общем виде элементы семантического поля связаны между собой парадигматическими отношениями. Семантический уровень языка представляет собой упорядоченную систему, элементы которой находятся в отношениях взаимосвязи и взаимообусловленности. Имея в виду связи между значениями слов, говорят о лексикосемантической системе языка или подъязыка. Элементами ее являются отобранные по определенным правилам лексические единицы естественного языка, а структура изоморфна структуре логических связей между понятиями специальной области знаний и деятельности. Задача моделирования понятийной системы фактически выходит за пределы лингвистики и является задачей описания и представления знаний. Ее можно разбить на две части: выявление системы понятий и выявление отношений между ними. Первая задача может решаться «вручную» путем экспликации и формализации профессионального знания, накопленного в системе человеческой деятельности, на основе знаний специалистов и с использованием имеющихся словарей, учебников и других пособий. Однако поскольку наши знания о мире так или иначе находят отражение в текстах, то можно поставить задачу извлечения системы понятий из текстов. Характер связей на этом первом этапе автоматически не устанавливается. В данной работе это выявление множества основных взаимосвязанных понятий вокруг выбранного ядерного элемента (ключевого слова).

Одним из старых и известных методов лингвистического исследования является дистрибутивно-статистический анализ, при котором используется информация о дистрибуции элементов текста и их числовых параметрах. 
Принцип перехода от изучения текстуальных связей (синтагматических) к системным (парадигматическим) лежит в основе различных дистрибутивно-статистических методик. Но чтобы можно было говорить о закономерности любых статистических распределений, нужны очень большие массивы данных. Таковые появились только с развитием созданием больших корпусов текстов.

Инструменты наполнения семантических полей встроены в некоторые корпусные менеджеры, напр., Sketch Engine, где исходным материалом является текстовый массив корпус текстов. В системе Sketch Engine имеется сервис «Тезаурус», выявляющий парадигматические (т. е. семантические) связи между терминами с количественным указанием силы этой связи. Тезаурус в системе Sketch Engine (или, как его можно охарактеризовать, дистрибутивный тезаурус) позволяет увидеть, какие слова имеют схожую дистрибуцию с заданным словом.

Для вычисления парадигматического подобия слов рассматриваются наборы сочетаемости для пар слов с учетом синтаксического отношения (лексические шаблоны). Единицы семантического поля обладают общими синтагматическими и парадигматическими свойствами, что отражает их семантическую близость. Схожесть дистрибуции слов высчитывается статистически на основе меры ассоциации logDice и с учетом лексико-синтаксических шаблонов.

Ниже приведен пример автоматического построения дистрибутивного тезауруса по корпусу текстов «Понятие империи в русской культуре» для лексемы империя с автоматическим разбиением его на кластеры (рис. 1) [3].

\begin{tabular}{|c|c|c|c|}
\hline \multicolumn{4}{|c|}{$\begin{array}{l}\text { империя } \\
\text { Rise_new_2 freq = } 989\end{array}$} \\
\hline Lemma & Score & Freq & Cluster \\
\hline государство & 0.31 & 1182 & страна $[0.203,807]$ европа $[0.172,921]$ религия $[0.161,573]$ общество $[0.139,697]$ человечество $[0.121,427]$ \\
\hline культура & 0.213 & 681 & цивилизация $[0.207,460]$ литература $[0.155,422]$ просвещение $[0.119,317]$ философия $[0.114,254]$ наука $[0.11,395]$ \\
\hline MhP & 0.202 & 1596 & церковь $[0.189,2088]$ народ $[0.174,2456]$ пленя $[0.131,835] \underline{\text { человек }}[0.117,2388]$ \\
\hline pИ世 & 0.197 & 662 & pусь $[0,186,704]$ византия $[0,122,323]$ \\
\hline россия & 0.186 & 2632 & \\
\hline монархия & 0.178 & 211 & христианство $[0.151,495]$ православие $[0.108,435]$ \\
\hline история & 0.177 & 1447 & жизнь $[0,155,1999]$ развитие $[0,127,805]$ \\
\hline царство & 0.176 & 492 & \\
\hline власть & 0.165 & 1168 & \\
\hline революция & 0.151 & 388 & война $[0.12,449]$ \\
\hline император & 0.141 & 272 & царь $[0,124,525]$ \\
\hline идея & 0.134 & 931 & политика $[0.114,238]$ мысль $[0.109,961]$ \\
\hline ropog & 0.134 & 449 & раскол $[0.116,172]$ \\
\hline семья & 0.133 & 361 & нация $[0,128,238]$ \\
\hline мение & 0,133 & 545 & $\operatorname{Agx}[0,12,909]$ вера $[0.116,1025]$ \\
\hline
\end{tabular}

Рис. 1. Гнездо тезауруса с выделенными кластерами для ключевого слова «империя»

В первом столбце приведены лексемы, во втором - значение статистической меры $\log$ Dice, в третьем - абсолютная частота лексемы в корпусе, в четвертом - лексемы, образующие с лексемой из первого столбца единый кластер (в квадратных скобках указаны значение меры и частота, им соответствующие). 


\section{4. Выявление семантических полей лексикографическими методами}

Другой подход, как уже говорилось, базируется на использовании имеющихся словарей, стандартов, нормативно-технической документации и т.п.

3.Д. Попова и И.А. Стернин в работе [4] отметили одну из основных методик описания концептов - анализ словарных толкований ключевого слова (имя заданного концепта) по возможно большему числу словарей, и из толкований делается выборка всех возможных характеристик концепта.

В данном исследовании мы пытаемся моделировать семантические поля «власть», «государство» и «империя», используя словарные статьи этих слов из словарей русского языка (разд. 8).

\section{5. Способы визуализации представления семантических полей}

После выявления основных лексических единиц, составляющих наполнение того ил иного концепта (на самом деле, это всегда значения), встает задача представить их в виде системы, т. е. показать отношения между ними, силу связи, и, возможно, использование в речи (в текстах).

Одним из известных проектов для русского языка является сервис RusVectōrēs, который «вычисляет семантические отношения между словами русского языка и позволяет скачать предобученные дистрибутивно-семантические модели (word embeddings)» [5]. Сервис строит лексические векторы, представляющие значение слова, автоматически извлеченное из статистики совместной встречаемости, через связи с другими словами (рис. 2).

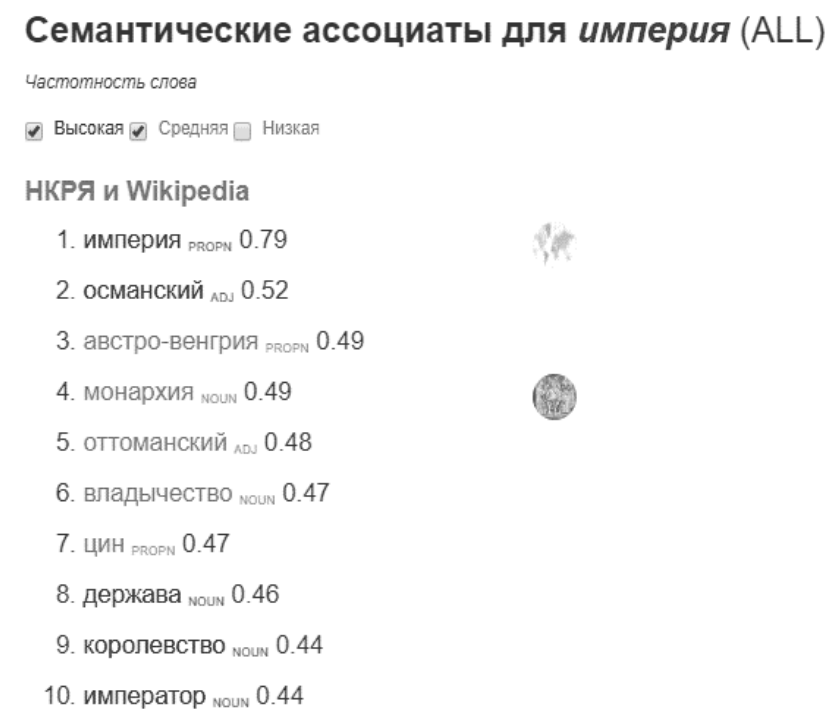

Рис. 2. Список из 10 ближайших семантических ассоциатов (квази-синонимов) слова «империя», сделанный при помощи сервиса RusVectōēēs

Одним из способов формального представления семантических полей является визуализация. Существует много способов компьютерной визуализации: облака тегов, графы, видеографы и т.д. Они основываются на списке выявленных лексических единиц и на числовых параметрах, характеризующих функционирование этих единиц в языке.

Облака тегов являются множеством ключевых слов или словосочетаний - тегов из текста, изображенных на плоскости или в трехмерном пространстве. Размер каждого тега зависит от частоты или любой другой частотной характеристики этого тега. Один из удобных 
инструментов для создания облаков тегов - функция «Тезаурус» в системе Sketch Engine (рис. 3).

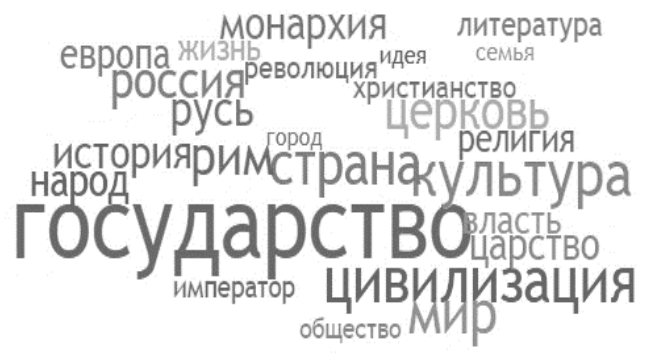

Рис. 3. Облако тегов для ключевого слова «империя» системы Sketch Engine

Кроме того, существуют другие, графические способы визуализации наполнения семантических полей. В проекте Semantic similarity of words Института языкознания им. Л. Штура Словацкой академии наук (https://korpus.sk/semä/) сформированное автоматически семантическое поле может быть представлено даже в трехмерном пространстве (рис. 4).

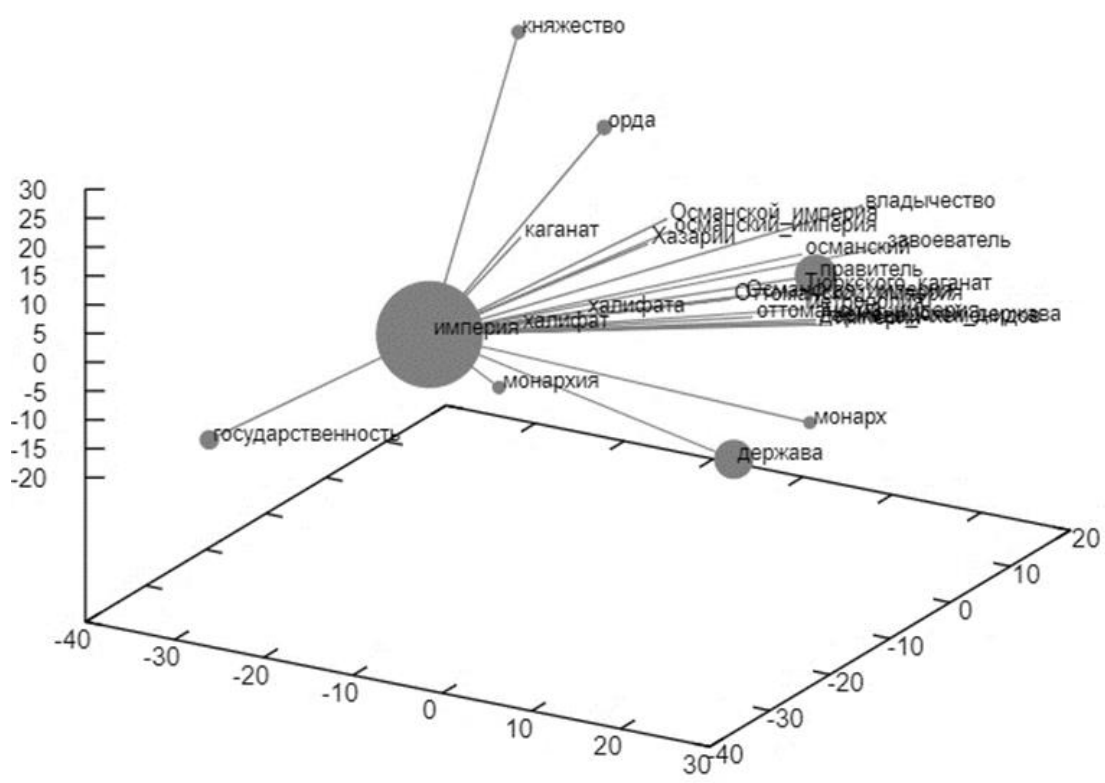

Рис. 4. Облако тегов для ключевого слова «империя» проекте Semantic similarity of words

\section{6. Интеллект-карта как способ компьютерной визуализации}

Также известен способ визуализации, получивший название «интеллект-карты». Интеллект-карту (mind map), известную также как ментальная карта, карта мыслей, ассоциативная карта или диаграмма связей, выдвинул британский психолог, писатель и лектор по проблемам эффективности мышления - Тони Бьюзен. Интеллект-карта - способ визуализации процесса общего системного мышления с помощью схем. Также может рассматриваться как удобная техника альтернативной записи [6]. 
По словам Т. Бьюзена, в основе интеллект-карте лежит принцип «радиантного мышления». «Радиантное мышление» - это ассоциативное мышление, отправной точной которого является центральный образ. От центрального образа во все направления расходятся лучи к границам листа. Над лучами пишут ключевые слова или рисуют образы, которые соединяют между собой ветвящимися линиями. Подобная запись позволяет интеллект-карте расти беспредельно и постоянно дополняться.

Интеллект-карта может применяться во многих сферах жизни и работы для того, чтобы совершенствовали интеллектуальный потенциал личности, решали разнообразные интеллектуальные задачи:

— обучение;

- конспектирование лекций;

- конспектирование книг;

- подготовка материала по определенной теме;

- решение творческих задач;

— мозговой штурм;

- презентации;

— планирование и разработка проектов разной сложности;

- составление списков дел;

- общение;

- проведение тренингов;

- развитие интеллектуальных способностей;

- визуализация лексической семантики.

В последнее десятилетие интеллект-карте посвящен ряд работ исследователей. Многие ученые уделяют большое внимание использовать интеллект-карты в педагогической деятельности: В работе Т. И. Щербаковой [7] исследуют применение интеллект-карт на уроках русского языка и литературы для развития творческого мышления учащихся. Е. А. Еремин [6] в своей статье изучает интеллект-карты как технологию представления базовых концепций учебного курса. Н. А. Позднякова [9] рассматривает интеллект-карты как метод подготовки учащихся к ОГЭ и ЕГЭ.

В статье С. А. Смирновой [10] исследуют создание и применение интеллект-карт как эффективное средство при изучении иностранного языка.

В то же время наблюдается применение метода интеллект-карты для решения лингвистических проблем. В работе А. Т. Шетиевой [11] рассматривает использование ментальной карты для описания концепта ИМПЕРАТИВ. В. П. Новикова [12] изучает интеллект-карты как эффективный инструмент работы с художественным текстом. С. В. Латышева и Щурик Н.В [13] в своей статье исследуют интеллект-карты для решения проблемы переводческого анализа научного текста.

Чтобы создать интеллект-карту, необходимо соблюдать следующие 4 принципа:

Первое, объект внимания или изучения находится в центральном образе;

Второе, основные темы, связанные с объектом внимания или изучения, расходятся от центрального образа в виде ветвей;

Третье, принимающие форму плавных линий, обозначаются и поясняются ключевыми словами или образами. Вторичные идеи также изображаются в виде ветвей, отходящих от ветвей более высокого порядка; то же справедливо для третичных идей и т.д.;

Четвертое, ветви формируют связанную узловую систему [14].

Достоинством интеллект-карты является структурированность информации и легкость получения общего представления о заложенных в карту знаниях. Однако к недостаткам следует отнести ограниченную масштабируемость и сфокусированность на единственном центральном понятии.

В данной работе мы попытаемся применить интеллект-карты как инструмент визуализации наполнения семантических полей «власть», «государство» и «империя». 


\section{7. Программы для создания интеллект-карт}

Интеллект-карты можно рисовать даже карандашом на бумаге, но в настоящее время существует много удобных программ для эффективного создания интеллект-карт, например, MindMeister, XMind, Freemind и т.д.

\subsection{MindMeister}

MindMeister - это один из онлайн-инструментов для рисования интеллект-карт. MindMeister является веб-приложением, поддерживает доступ к своим интеллект-картам прямо в веб-браузере. В этой программе есть стандартные шаблоны и возможность загружать свои картинки или фоны. У MindMeister есть бесплатная версия, на которой можно построить 3 интеллект-карты с ограниченными возможностями экспорта.

\subsection{XMind}

XMind представляет собой программное обеспечение для проведения мозговых штурмов, составления и редактирования интеллект-карт, разрабатываемое компанией XMind, которое в своей базовой версии доступно бесплатно. XMind может считывать существующие карты других программ, а также поддерживает формат FreeMind. Готовые интеллект-карты XMind можно экспортировать в виде текстового HTML-файла или сохранять в виде изображений.

Новейшая версия XMind (XMind 8) совместима с Mac OS X, OC Windows XP, Vista и выше. Программа также доступна и для смартфонов на Android и iOS.

\subsection{Freemind}

Программа Freemind является открытым бесплатным приложением, которое работает на платформе, поддерживающей Java. В целом программа имеет весь необходимый набор функций для создания качественных интеллект-карт. Программа дает возможность создавать схемы различных стилей и структур, добавлять ссылки, осуществлять поиск слов, скрывать отдельные части диаграммы и т.д. Минус этой программы - несовременный дизайн.

\subsection{MindManager}

MindManager - коммерческое программное обеспечение для управления интеллекткартами, разработанное Mindjet. Программа имеет как онлайн-версию, так и версию для смартфонов (Android, iOS). Карты MindManager могут быть экспортированы в Microsoft Word, PowerPoint, Visio и Project, coхранены как веб-страницы и в виде PDF документов. Программа платная с бесплатной пробной версией на месяц.

\subsection{Coogle}

Coggle является бесплатным онлайн приложением, поддерживающим совместную работу над проектами. В этой программе вы можете разрабатывать удобные красивые интеллект-карты.

Интерфейс программы прост, но в тоже время имеет множество функций, которые делают процесс создания интеллект карты чрезвычайно простым. Программа поддерживает использование изображений, индивидуальные цветовые схемы и возможность просмотра истории документа.

Хранение истории изменений позволяет вернуться к ранним версиям созданной карты, если в текущей версии возникли проблемы. Интеллект-карты, созданные в программе Coggle, могут экспортироваться в формате PNG или PDF 


\section{8. Компьютерная визуализация концептов «империя», «государство», «власть»}

Сначала для изучения концептов «империя», «государство», «власть» мы собрали словарные статьи слов «империя», «государство», «власть» из следующих русских словарей: Большой академический словарь, Словарь русского языка под редакцией А.П. Евгеньевой, Толковый словарь Ушакова, Большой толковый словарь русского языка, Толковый словарь русского языка С.И. Ожегова и Н.Ю. Шведовой, Толковый словарь современного русского языка, Толковый словарь русского языка Дмитриева, Толковый словарь Даля, Толковый словарь русского языка начала XXI века. актуальная лексика под редакцией Г. Н. Скляревской, Словарь иностранных слов под редакцией И.В. Лехина, Ф.Н. Петрова, Популярный словарь иностранных слов Музруковой Т. Г., Нечаевой И. В.. Мы выбрали из этих словарных статей слова, которые ассоциируются с исследуемыми нами концептами.

Например, мы разобрали словарные статьи «империя» из вышеуказанных словарей, выбрали из словарных толкований ключевые слова и словосочетания, которые, на наш взгляд, ассоциируются с концептом «империя», в частности: монархическое государство, глава, власть, римская империя, падение, титул, окраина, губерния, город, столица, владения, Британская империя, правления, Российская империя, монополия, контроль, газетная империя, США. Российская империя, опиумная империя, император, территория, держава, политика, угнетение, народ, организация, алмазная империя, нефтяная империя, властелин, Советский Союз, царь, граница и др.

Потом с помощью программы Xmind мы представили концепт «империя» на интеллекткарте (рис. 5). Точно такая же процедура была повторена для концептов «власть» и «государство» (рис. 6, 7).

\section{9. Анализ результатов}

Анализ полученных интеллект-карт показывает, мы имеем дело с привычным для тезаурусов иерархическим (древесным) представлением семантического поля. Покажем это на примере поля «империя». Построенное программой дерево (рис. 5) имеет несколько (от 1 до 3) уровней иерархии. Узлы (вершины) в этом дереве могут быть поименованы (организация, территория, народ) или нет, когда разные согипонимы (газетная, автомобильная, опиумная, алмазная) для наглядности собраны в одно гнездо. В этом случае узел фактически представлен гиперонимом (империя), который одновременно является синтагматическим узлом для вышеперечисленных коллокатов.

Разные ветви построенного дерева соответствуют разным парадигматическим отношениям, в частности:

- род-вид: империя - монархическое государство; организация - предприятие; территория - город, столица, провиниия, губерния, граница, дорога; власть - глава, царь, монах, правительвластелин;

— часть -целое: народ - гражданин;

- представитель класса: империя - США, СССР;

- ассоциация: армия, войска, война; суд - закон.

Мы видим также, что на рисунке представлены синтагматические связи: империя Франиузская, Римская, Английская, Российская, Британская, коммунистическая, тоталитарная. Но фактически здесь представлены те же системные, парадигматические отношения, где понятия представлены словосочетаниями: для пяти словосочетаний (Французская империя, Римская империя, Английская империя, Российская империя, Британская империя) это отношение «представитель класса», для двух последних (коммунистическая империя, тоталитарная империя) - отношение гипонимии. 


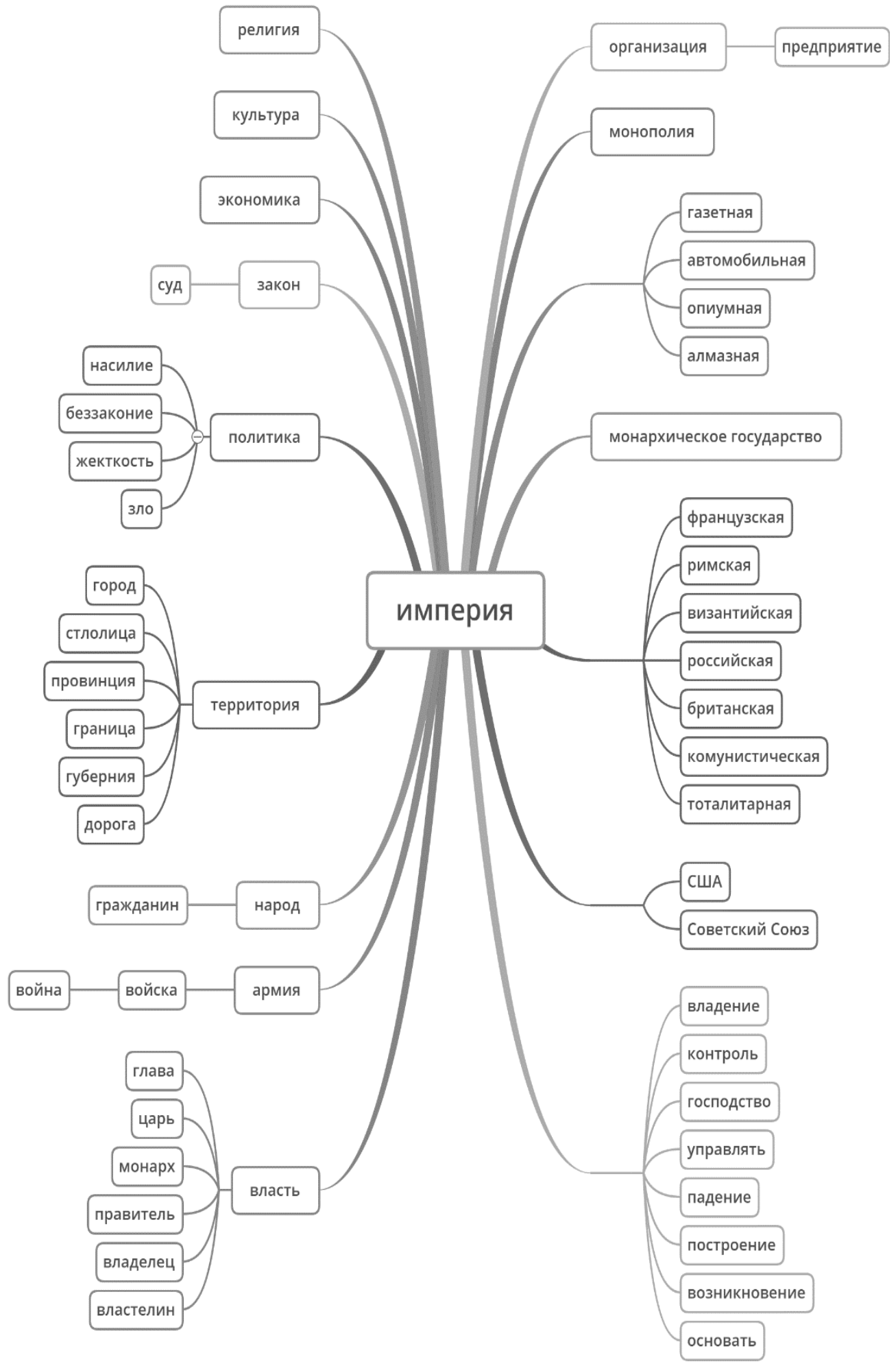

Рис. 5. Концепт «империя» в русской языковой картине мир 


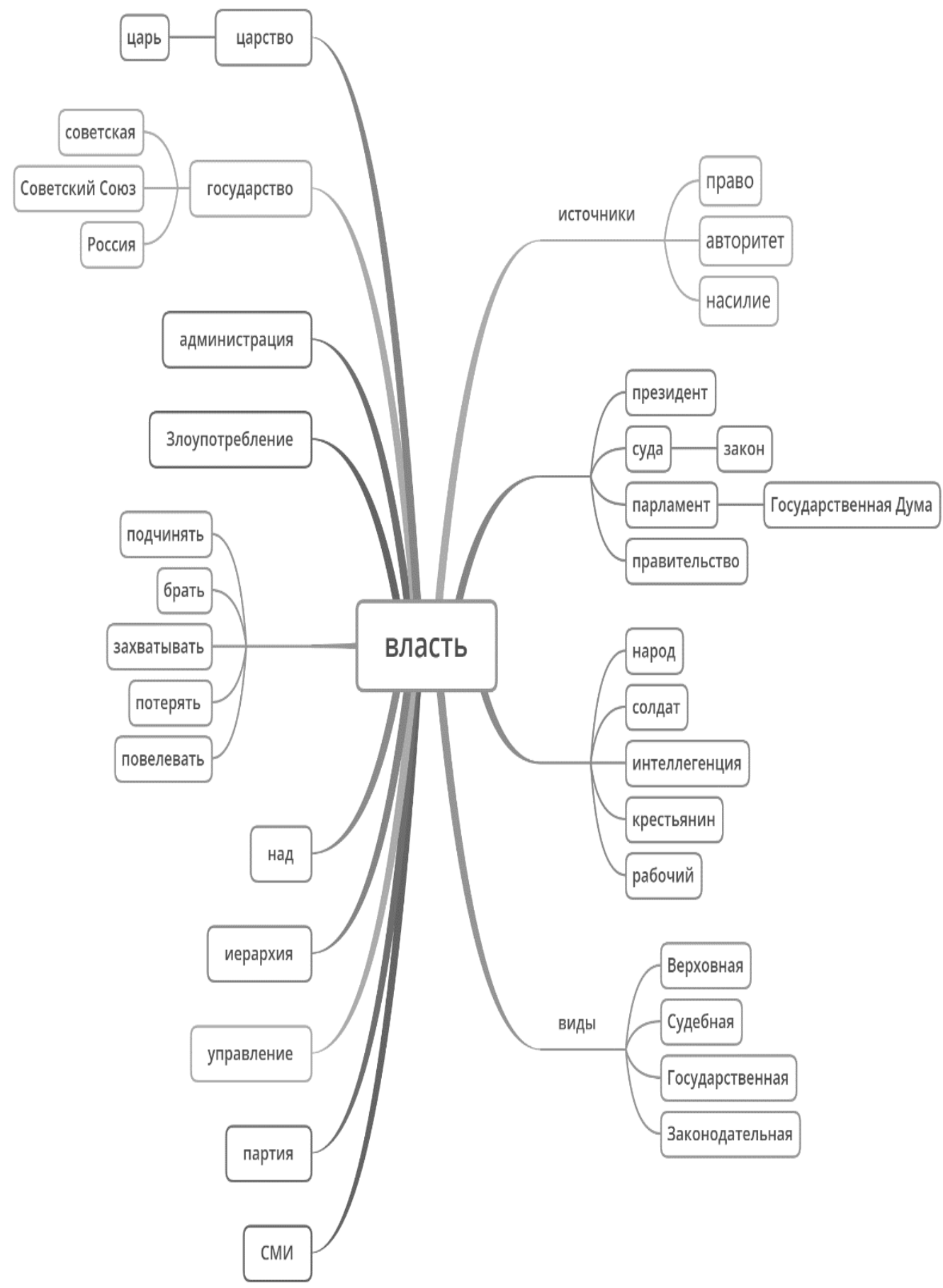

Рис. 6. Концепт «власть» в русской языковой картине мира 


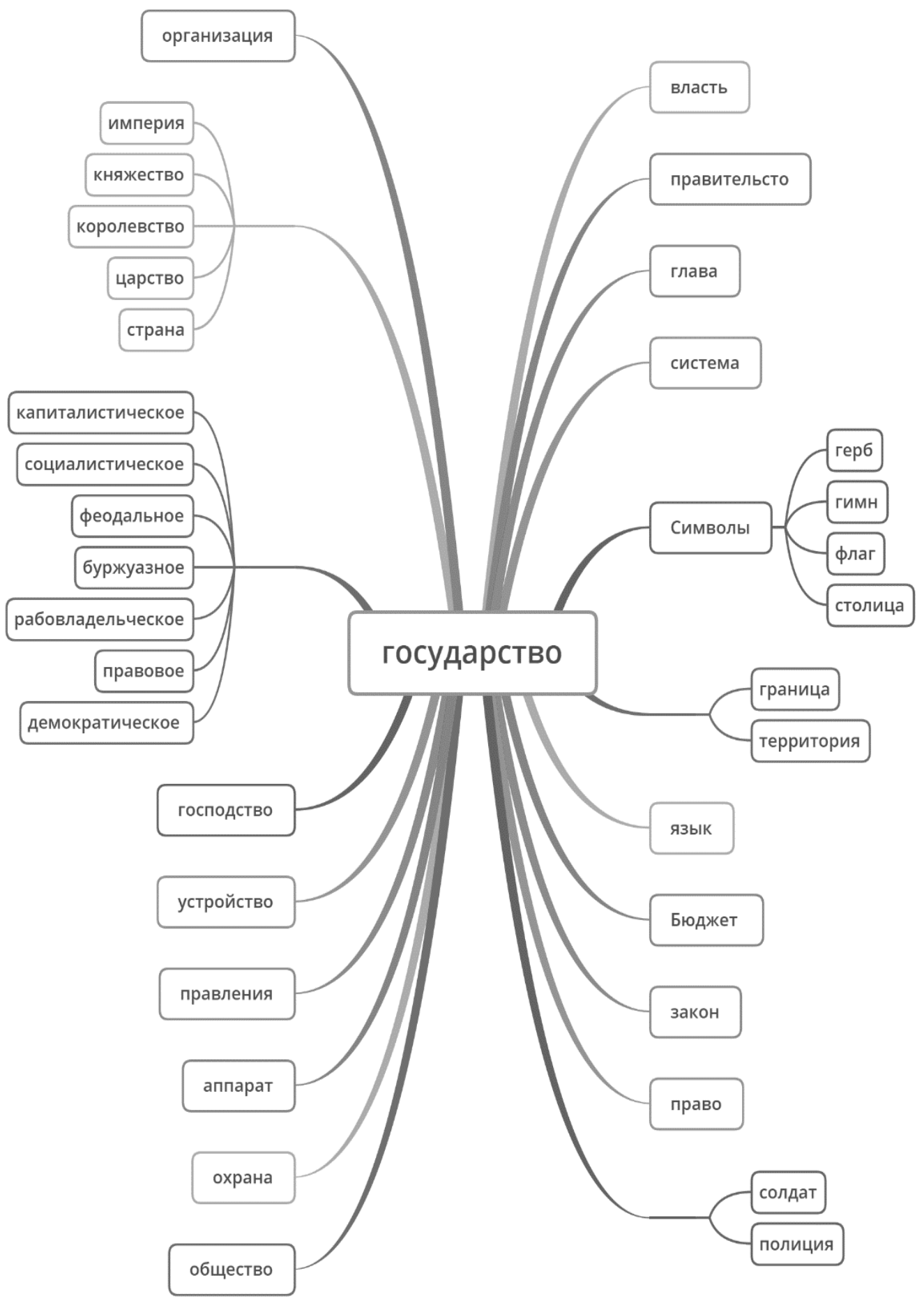

Рис. 7. Концепт «государство» в русской языковой картине мира 
Следует отметить, что для разных значений слова «империя» на рисунке имеются разные ветви: империя как государство представлено вышеперечисленными сочетаниями, империя как крупное предприятие, осуществляющее контроль над целой отраслью промышленности, характеризуется ветвью «империя - газетная, автомобильная, опиумная, алмазная». Отдельная ветвь в дереве представляет собой объектное (или субъектное) отношение: владение, контроль, господство, падение, построение, возникновение, управлять, основать. Оно представлено глаголами, отглагольными существительными или словами с предикативной семантикой.

\section{0. Заключение и перспективы}

Интеллект-карта является одним из удобных и популярных способов компьютерной визуализации. Существуют разные программы для создания интеллект-карт. В дальнейшем мы планируем провести сравнительный анализ возможностей всех этих программ.

Анализ данных на рисунках показывает, что разные концепты пересекаются по лексическому наполнению. Поэтому ставится задача построения интеллект-карт второго уровня для группы концептов.

Лексические единицы, выбранные нами для построения интеллект-карт, являются элементарными семантическими множителями. Однако очевидно, что некоторые из них должны быть объединены в устойчивые лексические комплексы, выражающие уникальные единые понятия. Поэтому перед этапом построения интеллект-карт должна выполняться предобработка лексикографических данных.

До сих пор интеллект-карты крайне редко применялись для представления лингвистических данных. Наша работа показывает, что с помощью интеллект-карт можно наглядно представить наполнение семантических полей.

Исследование поддержано грантом РФФИ № 18-012-00474 «Семантическое поле «империя» в русском, английском и чешском языках».

\section{Литература}

[1] Ipsen, G. The Ancient Orient and Indogermans Feast Scipts for W. Streitburg. Heidelberg, 1924. P. 30-45.

[2] Адмони В. Г. Синтаксис современного немецкого языка: Система отношений и система построения. Л.: Наука, 1973.

[3] Захаров В.П. Функциональность инструментов корпусной лингвистики // Труды международной конференции по компьютерной и когнитивной лингвистике TEL-2018. - В 2-х томах. Т 2. -Казань: Изд-во Академии наук РТ. 2018. С. 164 - 180.

[4] Попова 3.Д., Стернин И.А. Очерки по когнитивной лингвистике. Воронеж: Изд-во Воронежского ун-та, 2001.

[5] Kutuzov A., Kuzmenko E. WebVectors: A Toolkit for Building Web Interfaces for Vector Semantic Models. In: Ignatov D. et al. (eds) Analysis of Images, Social Networks and Texts. AIST 2016. Communications in Computer and Information Science, Springer, Cham. 2017. Vol 661. P. 155-161. DOI: 10.1007/978-3-319-52920-2 15.

[6] Бьюзен Б., Бьюзен Т. Супермышление. М.: Попурри, 2003.

[7] Щербакова Т.Н. Развитие творческого мышления у учащихся с помощью технологии интеллект-карт // Муниципальное образование: инновации и эксперимент. 2014. №3. С $45-61$.

[8] Еремин Е.А. Карты Mind Марs для учебника информатики // Вестник Пермского государственного гуманитарно-педагогического университета. Серия: Информационные компьютерные технологии в образовании. 2014. №10. С. 22 - 28.

[9] Позднякова Н.А. Использование интеллект-карт в системе подготовки к итоговой аттестации школьников по обществознанию // Символ науки. 2015. №8. С. 250 - 254. 
[10] Смирнова С.А. Создание и применение Mind Maps как эффективное средство при изучении иностранного языка в вузе // Вестник Костромского государственного университета. Серия: Педагогика. Психология. Социокинетика. 2017. №1. С. 143 - 146.

[11] Шетиева А.Р. Репрезентация концепта императив в формате интеллект-карты (методология исследования) // Вопросы когнитивной лингвистики. 2013. №4. С. 33 44.

[12] Новикова В.П. Интеллект-карта как эффективный инструмент работы с художественным текстом // Вопросы психолингвистики. 2016. №4. С. 156 - 163.

[13] Латышева С.В., Щурик Н.В. Интеллект-карта как метод обучения письменному переводу специализированных текстов: от анализа к синтезу // Вестник КемГУ. 2015. №2-3. С. $175-178$.

[14] Мюллер Х. Составление ментальных карт. Метод генерации и структурирования идей. Л., 2007.

\title{
Computerized visualization of the Russian language picture of the world
}

\author{
P. Zhang, V. Zakharov
}

\section{Saint Petersburg University}

The article deals with the visualization of the Russian language picture of the world. The linguistic picture of the world is an idea of the world that has developed in the ordinary consciousness of a given linguistic group. The concept is the basic element of the linguistic picture of the world, which can be realized in a word, phrase, statement, discourse, text, etc. Semantic fields, with which you can describe the lexical system of the language, are reflections of concepts. There are many ways to represent semantic fields: the intelligence map, the RusVectōrēs service, the word cloud, etc. The analysis of vocabulary interpretations of words in which a given concept is reflected is one of the main methods of concept presentation.

In the article, we analyze the Russian language picture of the world on the example of three concepts: empire, state, power, using dictionary entries of the words empire, state and power from different Russian dictionaries. The paper describes various ways of visualizing semantic fields. Mind map is considered as one of the important ways to visualize semantic word fields, which reflect concepts. It also describes the software for the formation of intelligence cards, in particular, MindMeister, XMind, Freemind, MindManager, Coogle.

Keywords: language picture of the world; concept; knowledge visualization; mind map

Reference for citation: Zhang P., Zakharov V. P. Computerized visualization of the Russian language picture of the world // Computer Linguistics and Computing Ontologies. Vol. 3 (Proceedings of the XXII International Joint Scientific Conference «Internet and Modern Society», IMS-2019, St. Petersburg, June 19-22, 2019). - St. Petersburg: ITMO University, 2019. P. 92 - 105. DOI: 10.17586/2541-9781-2019-3-92-105

\section{Reference}

[1] Ipsen, G. The Ancient Orient and Indogermans Feast Scipts for W. Streitburg. Heidelberg, 1924. P. 30-45.

[2] Admoni V. G. Sintaksis sovremennogo nemetskogo yazyka: Sistema otnosheniy i sistema postroyeniya. L.: Nauka, 1973.

[3] Zakharov V.P. Funktsional'nost' instrumentov korpusnoy lingvistiki // Trudy mezhdunarodnoy konferentsii po komp'yuternoyi kognitivnoy lingvistike TEL-2018. - V 2-kh tomakh. T 2. Kazan': Izd-vo Akademii nauk RT, 2018. P. 164 - 180. 
[4] Popova Z.D., Sternin I.A. Ocherki po kognitivnoy lingvistike. Voronezh: Izd-vo Voronezhskogo un-ta, 2001.

[5] Kutuzov A., Kuzmenko E. WebVectors: A Toolkit for Building Web Interfaces for Vector Semantic Models. In: Ignatov D. et al. (eds) Analysis of Images, Social Networks and Texts. AIST 2016. Communications in Computer and Information Science, Springer, Cham. 2017. Vol 661.

[6] Buzan B, Buzan T. Supermind. M.: Popurri, 2003.

[7] Shcherbakova T.N. Razvitiye tvorcheskogo myshleniya u uchashchikhsya s pomoshch'yu tekhnologii intellekt-kart // Munitsipal'noye obrazovaniye: innovatsii i eksperiment. 2014. №3. P. $45-61$.

[8] Yeremin Y.A. Karty Mind Maps dlya uchebnika informatiki // Vestnik Permskogo gosudarstvennogo gumanitarno-pedagogicheskogo universiteta. Seriya: Informatsionnyye komp'yuternyye tekhnologii v obrazovanii. 2014. №10. P. $22-28$.

[9] Pozdnyakova N.A. Ispol'zovaniye intellekt-kart v sisteme podgotovki k itogovoy attestatsii shkol'nikov po obshchestvoznaniyu // Simvol nauki. 2015. №8. P. 250 - 254.

[10]Smirnova S.A. Sozdaniye i primeneniye Mind Maps kak effektivnoye sredstvo pri izuchenii inostrannogo yazyka v vuze // Vestnik Kostromskogo gosudarstvennogo universiteta. Seriya: Pedagogika. Psikhologiya. Sotsiokinetika. 2017. №1. P. 143 - 146.

[11]Shetiyeva A.R. Reprezentaciya kontsepta imperativ $\mathrm{v}$ formate intellekt-karty (metodologiya issledovaniya) // Voprosy kognitivnoy lingvistiki. 2013. №4. P. 33 - 44.

[12]Novikova V.P. Intellekt-karta kak effektivnyy instrument raboty s khudozhestvennym tekstom // Voprosy psikholingvistiki. 2016. №4. P. 156 - 163.

[13]Latysheva S.V., Shchurik N.V. Intellekt-karta kak metod obucheniya pis'mennomu perevodu spetsializirovannykh tekstov: ot analiza k sintezu // Vestnik KemGU. 2015. №2-3. P. 175 178.

[14]Mueller K. Sostavleniye mental'nykh kart. Metod generatsii i strukturirovaniya idey. L. 2007. 